\title{
Variability of Hydrological Droughts in the Conterminous United States, 1951 through 2014
}

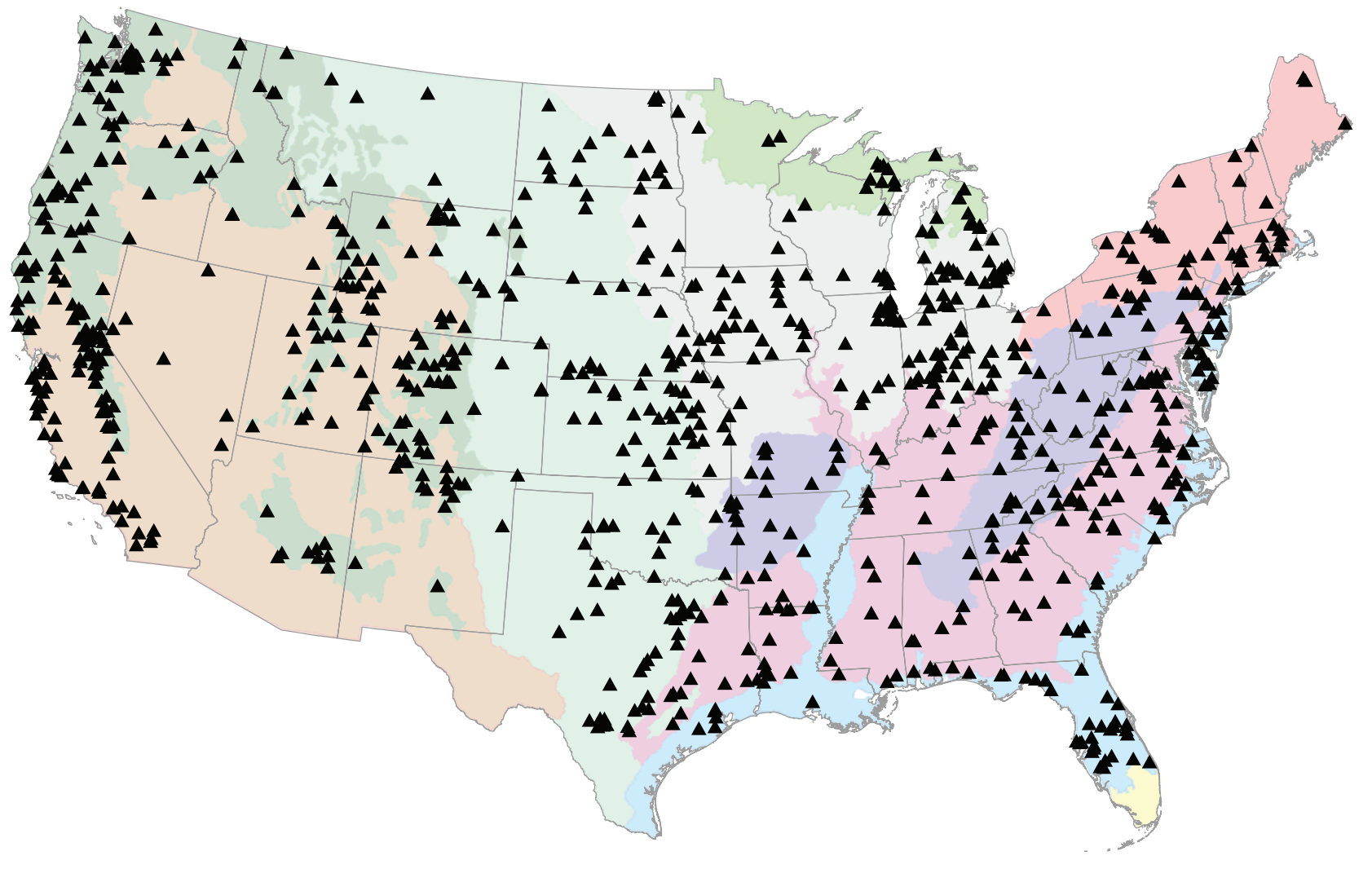

Scientific Investigations Report 2017-5099 



\section{Variability of Hydrological Droughts in the Conterminous United States, 1951 through 2014}

By Samuel H. Austin, David M. Wolock, and David L. Nelms

Scientific Investigations Report 2017-5099 


\title{
U.S. Department of the Interior \\ RYAN K. ZINKE, Secretary
}

\section{U.S. Geological Survey William H. Werkheiser, Deputy Director exercising the authority of the Director}

\author{
U.S. Geological Survey, Reston, Virginia: 2018
}

For more information on the USGS - the Federal source for science about the Earth, its natural and living resources, natural hazards, and the environment-visit https://www.usgs.gov or call 1-888-ASK-USGS.

For an overview of USGS information products, including maps, imagery, and publications, visit https://store.usgs.gov.

Any use of trade, firm, or product names is for descriptive purposes only and does not imply endorsement by the U.S. Government.

Although this information product, for the most part, is in the public domain, it also may contain copyrighted materials as noted in the text. Permission to reproduce copyrighted items must be secured from the copyright owner.

Suggested citation: Austin, S.H., Wolock, D.M., and Nelms, D.L., 2018, Variability of hydrological droughts in the conterminous United States, 1951 through 2014: U.S. Geological Survey Scientific Investigations Report 2017-5099, 16 p., https://doi. org/10.3133/sir20175099.

ISSN 2328-031X (print)

ISSN 2328-0328 (online) 


\section{Contents}

Abstract
Introduction.
Purpose and Scope
Previous Studies
Variability of Hydrological Droughts, 1951 Through 2014
Sempatial Variability
Comparison of Findings from This Study with Findings from Previous Investigations
Summary and Conclusions
Acknowledgments
References Cited




\section{Figures}

1. Map showing locations of streamgages used in the analysis of drought variability in the conterminous United States, 1951-2014..

2. Maps showing mean hydrological drought $A$, frequency, $B$, duration, and $C$, severity in the conterminous United States, 1951-2014.

3. Maps showing maximum drought $A$, duration and $B$, severity in the conterminous United States, 1951-2014

4. Graphs showing relation of mean maximum hydrological drought duration and severity to mean hydrological drought frequency in the conterminous United States, 1951-2014.

5. Maps showing differences in mean $A$, frequency, $B$, duration, and $C$, severity of droughts in the conterminous United States, 1983-2014 compared to 1951-82. .9

6. Map showing change in precipitation in the conterminous United States between a recent period (1983 through 2014) and an older period (1951 through 1982)

\section{Tables}

1. Hydrological drought summary statistics for the conterminous United States, by ecoregion, 1951 through 2014.

2. Changes in hydrological drought frequency, duration, and severity in the conterminous United States for a recent period (1983-2014) compared to an older period (1951-82), by ecoregion, 609 sites experienced drought in both time periods. 


\section{Conversion Factors}

International System of Units to Inch/Pound

\begin{tabular}{lcc}
\hline \multicolumn{1}{c}{ Multiply } & By & To obtain \\
\hline & Length & \\
\hline millimeter $(\mathrm{mm})$ & 0.03937 & inch (in.) \\
kilometer $(\mathrm{km})$ & 0.62137 & mile (mi.) \\
\hline
\end{tabular}

\section{Abbreviations}

CONUS Conterminous United States

GCM General Circulation Model

$\mathrm{mm} \quad$ millimeter

PDSI Palmer Drought Severity Index

USGS U.S. Geological Survey 



\title{
Variability of Hydrological Droughts in the Conterminous United States, 1951 through 2014
}

\author{
By Samuel H. Austin, David M. Wolock, and David L. Nelms
}

\section{Abstract}

Spatial and temporal variability in the frequency, duration, and severity of hydrological droughts across the conterminous United States (CONUS) was examined using monthly mean streamflow measured at 872 sites from 1951 through 2014. Hydrological drought is identified as starting when streamflow falls below the 20th percentile streamflow value for 3 consecutive months and ending when streamflow remains above the 20th percentile streamflow value for 3 consecutive months. Mean drought frequency for all aggregated ecoregions in CONUS is 16 droughts per 100 years. Mean drought duration is 5 months, and mean drought severity is 39 percent on a scale ranging from 0 percent to 100 percent (with 100\% being the most severe). Hydrological drought frequency is highest in the Western Mountains aggregated ecoregion and lowest in the Eastern Highlands, Northeast, and Southeast Plains aggregated ecoregions. Hydrological drought frequencies of 17 or more droughts per 100 years were found for the Central Plains, Southeast Coastal Plains, Western Mountains, and Western Xeric aggregated ecoregions. Drought duration and severity indicate spatial variability among the sites, but unlike drought frequency, do not show coherent spatial patterns. A comparison of an older period (1951-82) with a recent period (1983-2014) indicates few sites have statistically significant changes in drought frequency, drought duration, or drought severity at a 95-percent confidence level.

\section{Introduction}

As the global climate has warmed there has been increasing concern that climate change will have substantial effects on the occurrence and severity of hydrological droughts (Rind and others, 1990; Hoerling and Eischeid, 2007; Seager and others, 2007; Sheffield and Wood, 2008; Dai, 2011a; Dai, 2011b; Dai, 2013), which are defined here as periods of below-normal streamflow (Maidment, 1992; Patterson and others, 2013). Although a number of studies have examined drought occurrence (Andreadis and others, 2005; Sheffield and others, 2009; McCabe and Wolock, 2014), relatively few investigations have described the spatial and temporal variability of hydrological droughts in the United States (Patterson and others, 2013). In one of the most complete analyses of droughts in the United States, Andreadis and others (2005) examined the duration, frequency, severity, and extent of agricultural and hydrological droughts across the United States during 1925-2003. In their analyses, Andreadis and others (2005) used model-simulated soil-moisture storage and runoff to quantify agricultural droughts and hydrological droughts, respectively. Andreadis and others (2005) found that the droughts in the 1930s and 1950s were the most severe largearea droughts of the 20th century, whereas the early 2000s drought in western United States was among the most severe for small areas and short durations. Additionally, Andreadis and others (2005) found that the most severe agricultural droughts were associated with the most severe hydrological droughts.

This study builds on the work of Andreadis and others (2005) and amplifies the work of Patterson and others (2013). In a study of hydrological droughts in southeastern United States, Patterson and others (2013) defined a hydrological drought as a period when monthly mean streamflow falls below the 20th percentile value for a specific site for 3 consecutive months and ends when the streamflow remains above the 20th percentile streamflow value for 3 consecutive months. Patterson and others (2013) found that 71 percent of droughts were shorter than 6 months, whereas only 7 percent were multiyear events. They also report that there was little evidence of long-term increases or decreases in drought characteristics in the southeastern United States during the 20th century.

This study used measured streamflow data rather than model-simulated data, which were used by Andreadis and others (2005). This study also evaluated hydrological drought characteristics for streams throughout the conterminous United States (CONUS) rather than those confined to southeastern United States, as identified by Patterson and others (2013).

\section{Purpose and Scope}

This report documents characterizations of hydrological droughts empirically determined using the methodology articulated by Patterson and others (2013) for streamflow data for the entire CONUS. The characterization of the spatial and temporal variability of hydrological droughts for the entire CONUS from 1951 through 2014 complements the work of Andreadis and others (2005) and Patterson and others (2013).

In this report, mean drought frequency, duration, and severity are illustrated in figures. Statistics on hydrological 


\section{Variability of Hydrological Droughts in the Conterminous United States, 1951 through 2014}

droughts are listed in tables and are available in a companion data release at https://doi.org/10.5066/F70C4T19.

\section{Previous Studies}

Hydrological droughts have been quantified in previous studies using various methods (Downer and others, 1967; Llamas and Siddiqui, 1969; Sen, 1976, 1980a,b; Dracup and others, 1980a, b; Frick and others, 1990; Loaiciga and Leipnik, 1996; Fernández and Salas, 1999a, b; Mishra and Singh, 2011). Yevjevich (1967) introduced an objective approach to the definition and investigation of continental hydrological droughts, describing concepts and a theory of runs used in the probabilistic characterization of droughts. Significant research on the probabilistic characterization of droughts has been done since Yevjevich (1967), and the research demonstrated that hydrological droughts often exhibit probabilistic characteristics (Sen, 1980a; Loaiciga and Leipnik, 1996; Chung and Salas, 2000; Mishra and others, 2009). Karl and others (1987) used the Palmer Drought Severity Index (PDSI) to investigate the approximate precipitation required to ameliorate or terminate any ongoing drought across the CONUS. Strzepek and others (2010) forecasted the effect of climate change on the frequency and intensity of droughts in the CONUS over the 21 st century and computed standardized precipitation indices, such as the PDSI using output from General Circulation Models (GCM) for three emissions scenarios. Nalbantis and Tsakiris (2009) developed a methodology for forecasting hydrological drought severity using a simple index of cumulative streamflow from overlapping monthly periods within each hydrological year in a non-stationary Markov chain. Cayan and others (2010) forecasted future dryness in the southwestern United States using hydrological models from downscaled climate change simulations. Groisman and others (2004) summarize in situ observed trends in contemporary changes of the hydrological cycle for the CONUS and suggest that physical models of the global climate system are best at identifying the causes of observed trends.

\section{Methods of Study}

Daily streamflow data were obtained from the U.S. Geological Survey (USGS) National Water Information System (http://waterdata.usgs.gov/nwis) for streamgages listed in version 2 of the USGS Geospatial Attributes of Gages for Evaluating Streamflow (GAGES-II) dataset (Falcone and others, 2011). These sites are considered USGS reference gages, representing hydrologic conditions which are least disturbed by human influences as compared to other watersheds. Their drainage areas range from 0.21 square kilometer $\left(\mathrm{km}^{2}\right)$ to $49,802 \mathrm{~km}^{2}$. No further differentiation, such as the degree of flow regulation, was made beyond this identification of reference condition. Sites with records that are at least 80 percent complete for calendar years 1951 through 2014 were used for the analyses ( 872 sites, fig. 1). Drainage areas of these sites range from $3 \mathrm{~km}^{2}$ to $47,725 \mathrm{~km}^{2}$. The daily streamflow data for each of the selected sites were aggregated to provide calendar year time series of monthly mean streamflow for each site (Austin and others, 2018).

The monthly mean streamflow values for each site were converted to monthly percentile values on the basis of the period of record for each site. For example, the lowest and highest January monthly flow values at a site were assigned values of 1 and 100, respectively. Characteristics of hydrological drought then were identified using the methodology presented by Patterson and others (2013). Per Patterson and others (2013), hydrological drought begins when streamflow falls below the 20th percentile streamflow value for 3 consecutive months and ends when streamflow remains above the 20th percentile streamflow value for 3 consecutive months. Other studies have used similar thresholds to define drought (Andreadis and others, 2005; Sheffield and others, 2009). Three hydrological drought characteristics were computed: (1) drought frequency, (2) drought duration, and (3) drought severity. Drought frequency was computed as the number of droughts over the period of record divided by the number of years in the period of record multiplied by 100 to express frequency as the number of droughts likely to occur on average within a 100 -year period. Drought duration (D) is defined as the number of months counted from the beginning of the drought period to the end of the drought period. Drought severity (S) was computed as

$$
\mathrm{S}=100-\left(\mathrm{P}_{\text {ave }}\right)
$$

where

$$
\begin{aligned}
& \mathrm{P}_{\text {ave }} \quad \text { is the sum of monthly mean streamflow } \\
& \text { percentiles during a drought divided by } \\
& \text { the duration of the drought }\left(\frac{\Sigma P}{D}\right) \text { normalized } \\
& \text { to a scale of } 0 \text { percent (least severe) to } \\
& 100 \text { percent (most severe). }
\end{aligned}
$$

The mean percentile departure value was subtracted from 100 so that higher values of drought severity indicate lower magnitude flow conditions (Patterson and others, 2013). Note that the methodology employed in this study to define drought periods does not identify short-term (less than 3 months) droughts. 


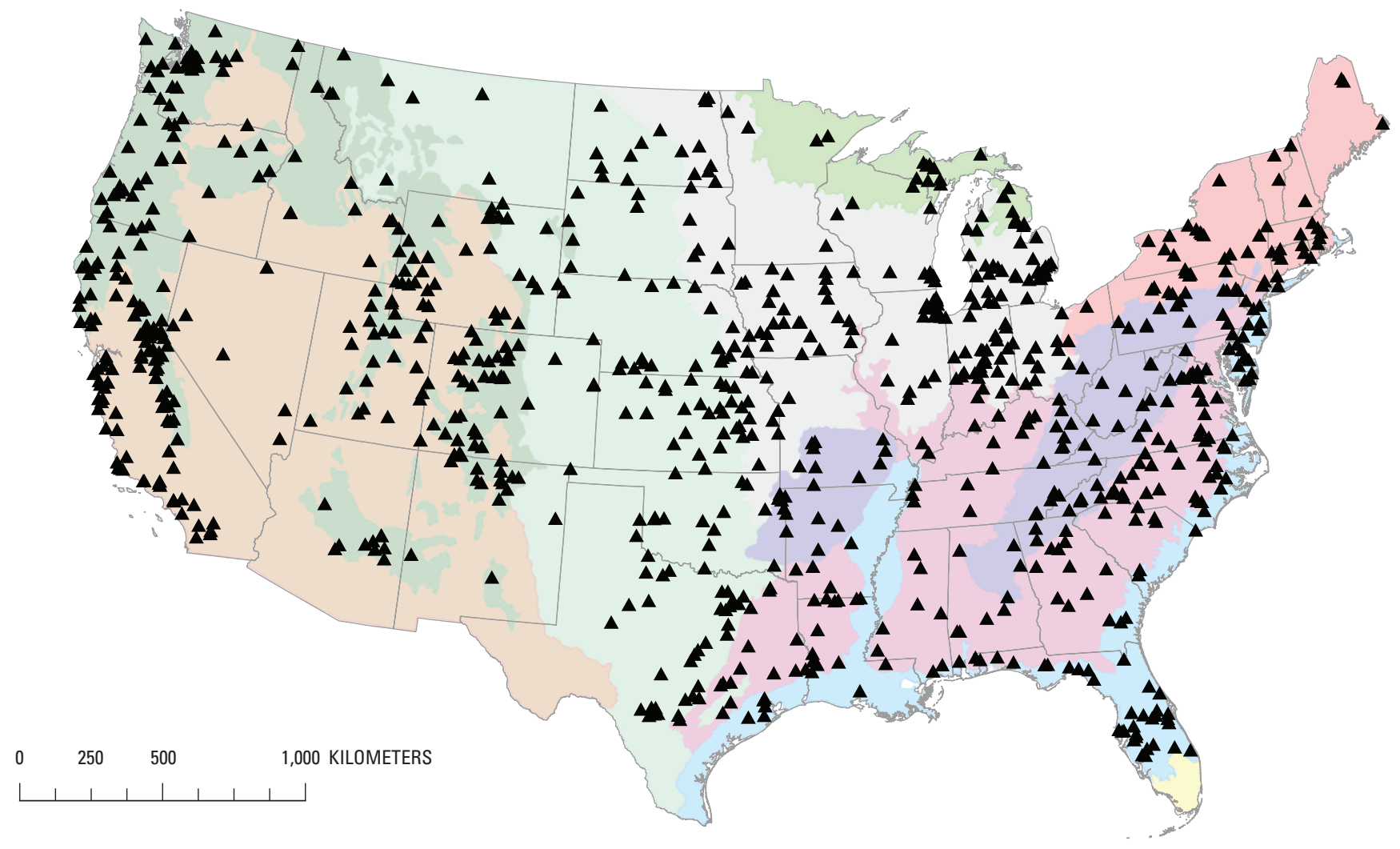

Base from U.S. Geological Survey, 1994, The National Map: State Boundaries of the Conterminous United States, 1:2,000,000.

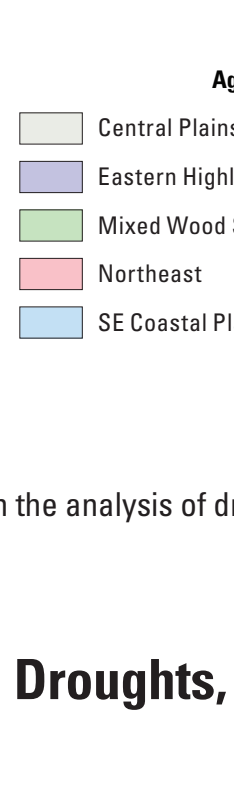

This study examined the spatial and temporal variability of drought frequency, duration, and severity, providing an empirically determined characterization of hydrological droughts. Spatial and temporal variability of hydrological droughts from 1951 through 2014 were evaluated using measured streamflow data rather than model-simulated data, and evaluations of hydrological drought characteristics were made for streams throughout the entire CONUS rather than those of a particular region. Results are presented for the CONUS and associated with 9 of 10 aggregated ecoregions, after Falcone and others (2011), to facilitate summary and discussion. No information is provided for the South Florida aggregated ecoregion (fig. 1).

\section{Spatial Variability}

For the CONUS, the mean hydrological drought frequency (the number of droughts per 100 years) is 16 , which is about one drought every 6 years on average (fig. $2 A$, table 1). Hydrological drought frequency is highest in the Western Mountains (19) and lowest in the Eastern Highlands (12), Northeast (12), and Southeast Plains (12).

Mean hydrological drought duration for the CONUS is 5 months (fig. $2 B$, table 1), and the mean drought severity for 


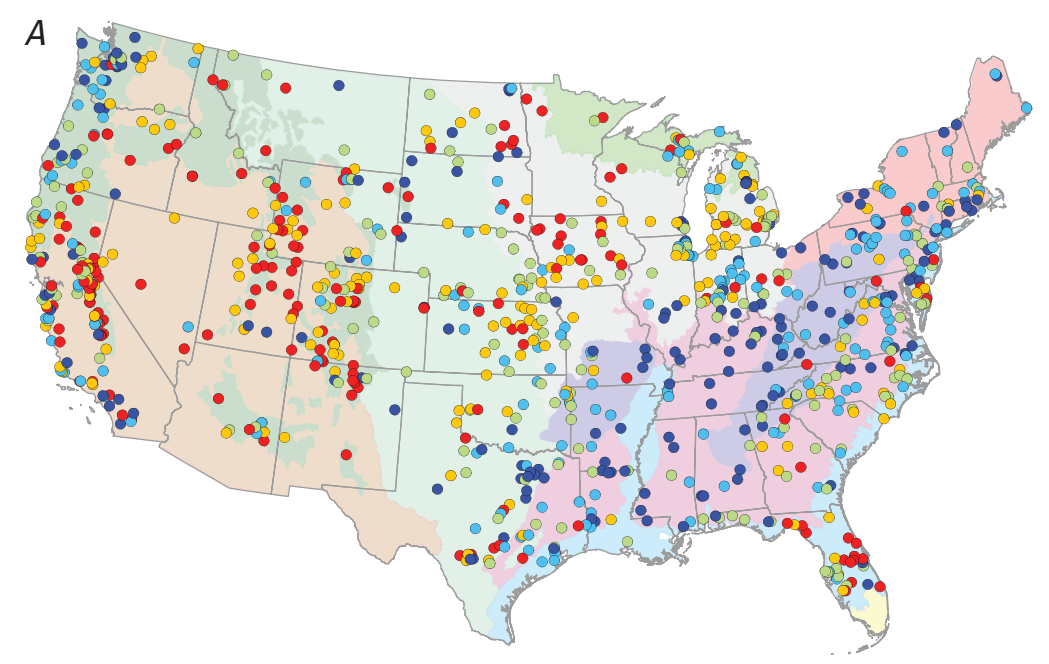

\section{EXPLANATION}

\begin{tabular}{|c|c|}
\hline Aggregated ecoregion & $\begin{array}{l}\text { Mean frequency } \\
\text { (droughts per } 100 \text { years' }\end{array}$ \\
\hline Central Plains & fur \\
\hline Eastern Highlands & \\
\hline Mixed Wood Shield & 9.8 to 14.3 \\
\hline Northeast & 14.4 to 18.1 \\
\hline ivortileast & 18.2 to 22.1 \\
\hline SE Coastal Plains & $222+0369$ \\
\hline SE Plains & \\
\hline South Florida & \\
\hline Western Mountains & \\
\hline Western Plains & \\
\hline Western Xeric & \\
\hline
\end{tabular}

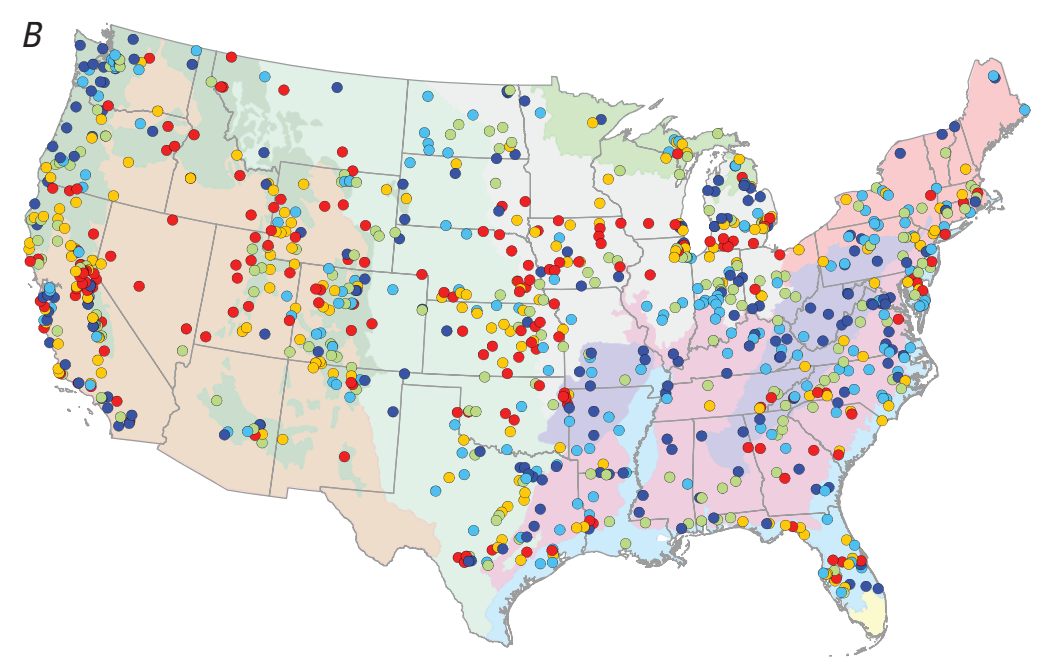

EXPLANATION

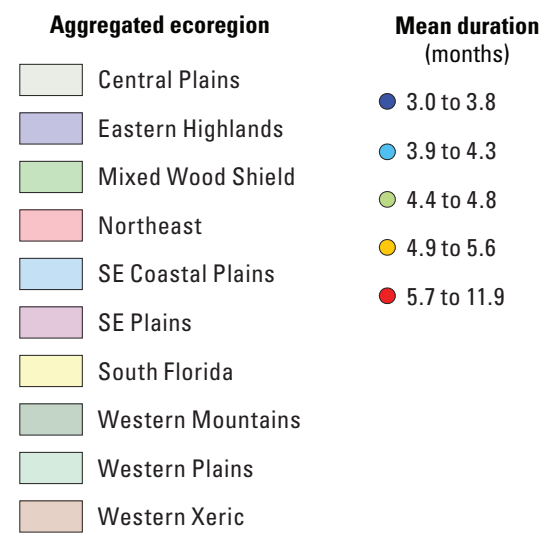

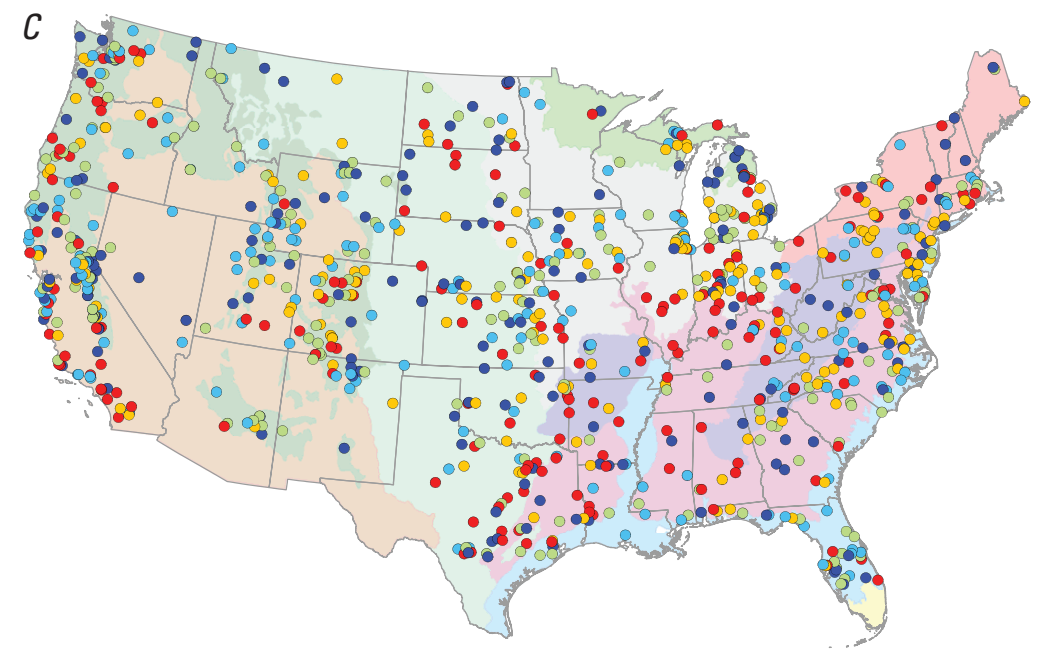

EXPLANATION

Base from U.S. Geological Survey, 1994,

The National Map: State Boundaries of the

0
$250 \quad 500 \quad 1,000$ KILOMETERS

Conterminous United States, 1:2,000,000.

Figure 2. Mean hydrological drought $A$, frequency, $B$, duration, and $C$, severity in the conterminous United States, 1951-2014. Colored dots show magnitude. Colored areas show aggregated ecoregions. (SE, Southeast) 


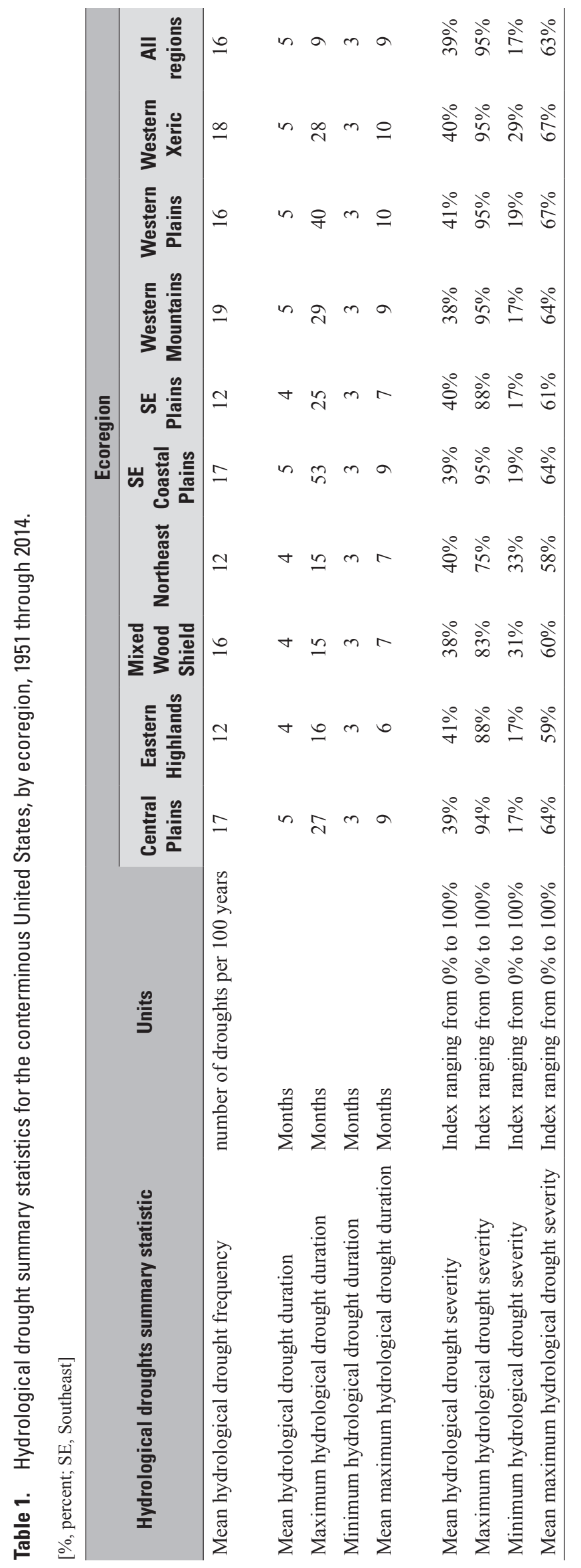




\section{Variability of Hydrological Droughts in the Conterminous United States, 1951 through 2014}

the CONUS is 39 percent (fig. $2 C$, table 1). Unlike drought frequency, there are no aggregated ecoregions in which drought duration and severity are consistently high or low. Areas of coherent high mean drought duration include parts of the Rocky Mountains and east-central California, whereas low mean drought duration occurred in parts of the Pacific Northwest, the southern California coast, the Mid-Atlantic region, and northern New England. Areas of high mean drought severity are found in parts of southern California, eastern Texas, and the southern Mississippi basin. Areas of low mean drought severity are found in parts of the Rocky Mountains, Michigan, and Florida (figs. $2 B$ and $2 C$, table 1 ).

Of special concern are long droughts expressed as maximum drought duration. The mean value of the maximum drought duration for all sites is 9 months, with a maximum drought duration of 53 months and a minimum drought duration, as a consequence of our methodology, of 3 months (fig. $3 A$, table 1). The longest of all droughts occurred in the Southeast Coastal Plain (53 months) followed by a drought in the Western Plains (40 months). Mean maximum drought durations were longest in the Western Xeric (10 months) and the Western Plains (10 months) aggregated ecoregions, and the shortest durations were in the Eastern Highlands (6 months).

Drought severities among all of the sites ranged from 17 percent to 95 percent (fig. $3 B$, table 1). The highest drought severity rating $(95 \%)$ occurred for the Southeast Coastal Plain, Western Mountains, Western Plains, and Western Xeric aggregated ecoregions. The lowest drought severity rating (17\%) occurred in the Central Plains, Eastern Highlands, Southeast Plains, and Western Mountains aggregated ecoregions.

Among aggregated ecoregions, mean maximum hydrological drought duration and drought severity varied with mean hydrological drought frequency, with lower values of mean maximum drought duration and severity corresponding to lower values of mean drought frequency, and higher values of mean maximum drought duration and severity corresponding to higher values of mean drought frequency. Most low values of mean maximum hydrological drought duration and severity were associated with aggregated ecoregions in the eastern CONUS, except the Southeast Coastal Plain, and high values were associated with aggregated ecoregions in the western CONUS (fig. 4).

\section{Temporal Variability}

To examine temporal changes, the mean drought statistics (frequency, duration, and severity) for an older period (1951-82) were subtracted from the mean statistics for a recent period (1983-2014), and the differences in drought frequency, duration, and severity were mapped. Positive differences indicate greater frequency, duration, and severity in the more recent period (fig. 5). Drought duration and drought severity values at each site were grouped by time period, and student t-tests were used to compare the grouped means at each site, identifying long-term statistically significant differences in drought duration and severity at a 95-percent confidence level $(p<0.05)$. Because student t-tests compare significant differences in the means of two groups of values, having one frequency value available for each site for each time period precludes student t-tests of frequency differences at each site. Sites were therefore grouped by region, and student t-tests were used to identify the long-term statistically significant differences in drought frequency for the group of sites in each region at a 95-percent confidence level $(p<0.05)$.

Changes in drought frequency (mean frequency 1983-2014 minus mean frequency 1951-82) are variable across the CONUS. Overall, 51 percent of sites experienced a decrease in drought frequency, 40 percent experienced an increase in drought frequency, and 9 percent experienced no change. Five of 9 aggregated ecoregions (Eastern Highlands, Southeast Coastal Plain, Western Mountains, Western Plains, and Western Xeric) exhibited changes in drought frequencies that are not statistically significant $(p<0.05)$. Four aggregated ecoregions (Central Plains, Mixed Wood Shield, Northeast, and Southeast Plains), all associated with the eastern part of the CONUS, exhibited statistically significant drought frequency differences (fig. $5 A$-inset, table 2). Drought frequencies decreased in the Central Plains and Northeast but increased in the Mixed Wood Shield and Southeast Plains. In the Central Plains, 88 of 108 sites have decreased drought frequency ( $81 \%$ ), followed by the Northeast with 32 of 44 sites with decreased drought frequency (73\%). The Mixed Wood Shield had 8 of 12 sites with increased drought frequency (67\%), followed by the Southeast Coastal Plain with 24 of 42 sites with increased drought frequency (57\%). Parts of some aggregated ecoregions exhibit clusters of sites with coherent changes in drought frequency. For example, drought frequency has increased in parts of the southeastern United States-Texas, California, the Western Mountains, and the Mixed Wood Shield (red and orange points fig. 5A).

Changes in drought duration and drought severity also have been variable across the CONUS; regions of similar changes in these drought statistics are not apparent (figs. $5 B$, $5 C$, table 2). Overall, 49 percent of sites experienced a decrease in drought duration, 47 percent experienced an increase in drought duration, and 4 percent experienced no change in drought duration. However, 56 percent of sites experienced a decrease in drought severity, and 44 percent experienced an increase in drought severity (table 2). Drought duration and drought severity differences were calculated for the 609 sites that experienced drought in both time periods (1983-2014 and 1951-82); most of the differences were not statistically significant $(p<0.05)$ (figs. $5 B$-inset, $5 C$-inset, table 2). Parts of northern California, southern Oregon, and the area from Texas to Virginia, however, show that most sites have increased drought durations (red and orange points fig. $5 B$ ), and increased drought severity predominates in parts, but not all, of the Southeast, Western Plains, and Western Mountains (red and orange points 5C). In the Southeast Plains, 46 of 75 sites have increased drought duration (61\%), and 42 of 75 sites have increased drought severity (56\%). In the Western 


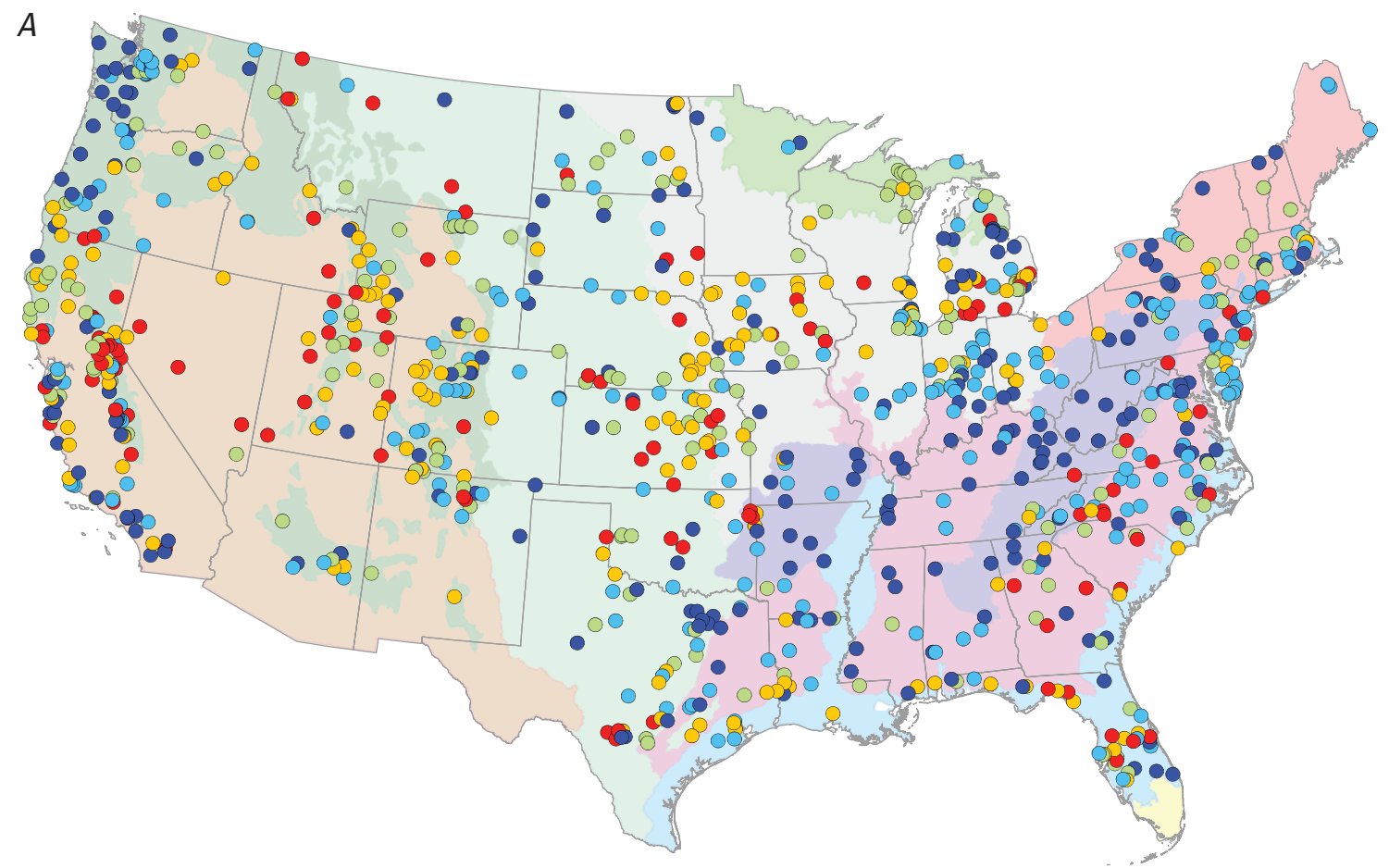

\section{EXPLANATION}

Aggregated ecoregion

Central Plains

Eastern Highlands

Mixed Wood Shield

Northeast

SE Coastal Plains

SE Plains

South Florida

Western Mountains

Western Plains

Western Xeric

Maximum duration (months)

- 3 to 5

- 6 to 7

० 8 to 9

- 10 to 12

- 13 to 53

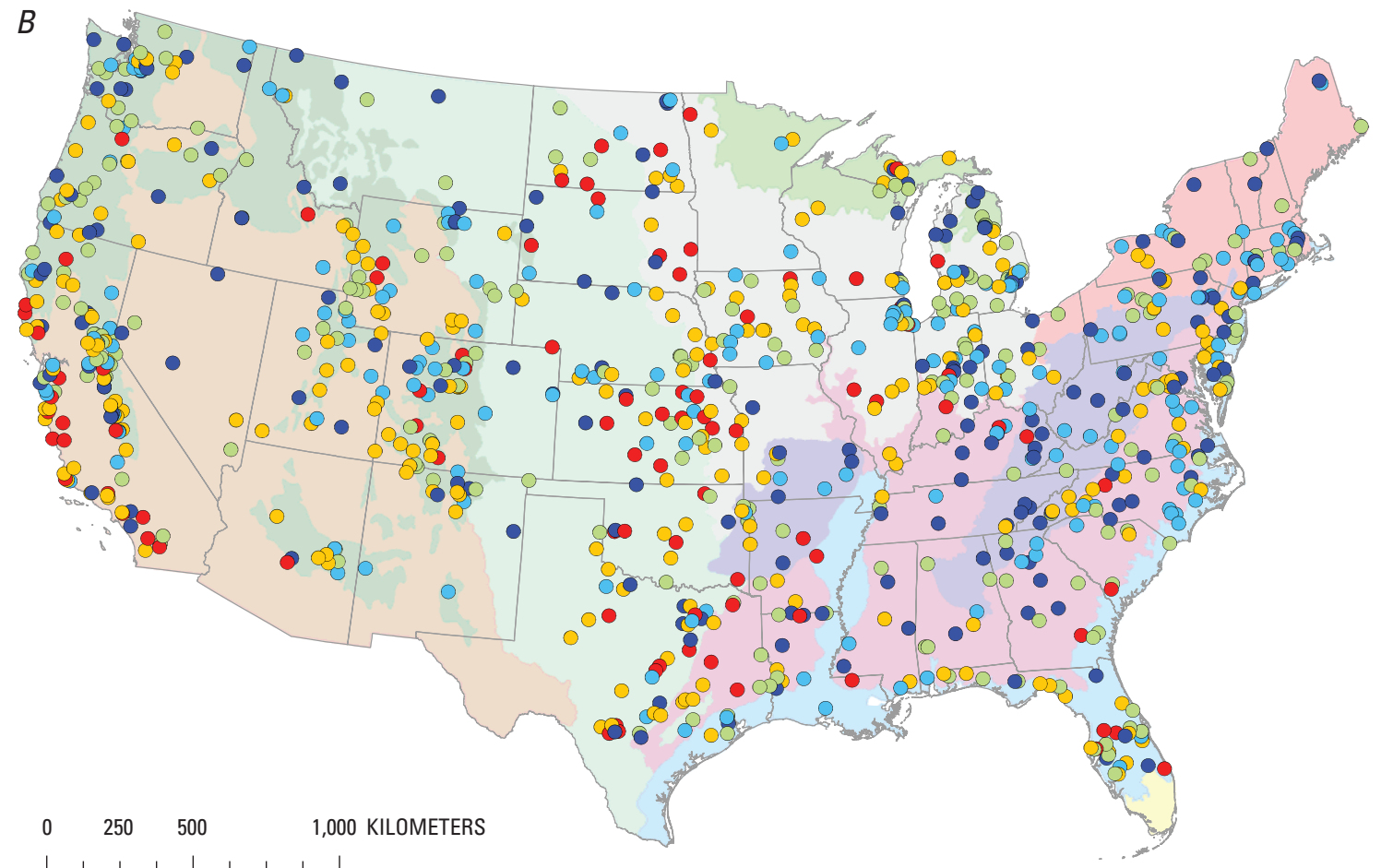

EXPLANATION

Aggregated ecoregion

Central Plains

Eastern Highlands

Mixed Wood Shield

Northeast

SE Coastal Plains

SE Plains

South Florida

Western Mountains

Western Plains

Western Xeric

Maximum severity (scaled from 0 to 100)

- 0 to 54

O 55 to 61

○ 62 to 67

○ 68 to 75

- 76 to 95

Base from U.S. Geological Survey, 1994, The National Map: State Boundaries of the Conterminous United States, 1:2,000,000.

Figure 3. Maximum drought $A$, duration and $B$, severity in the conterminous United States, 1951-2014. Colored dots show magnitude. Colored areas show aggregated ecoregions. (SE, Southeast) 

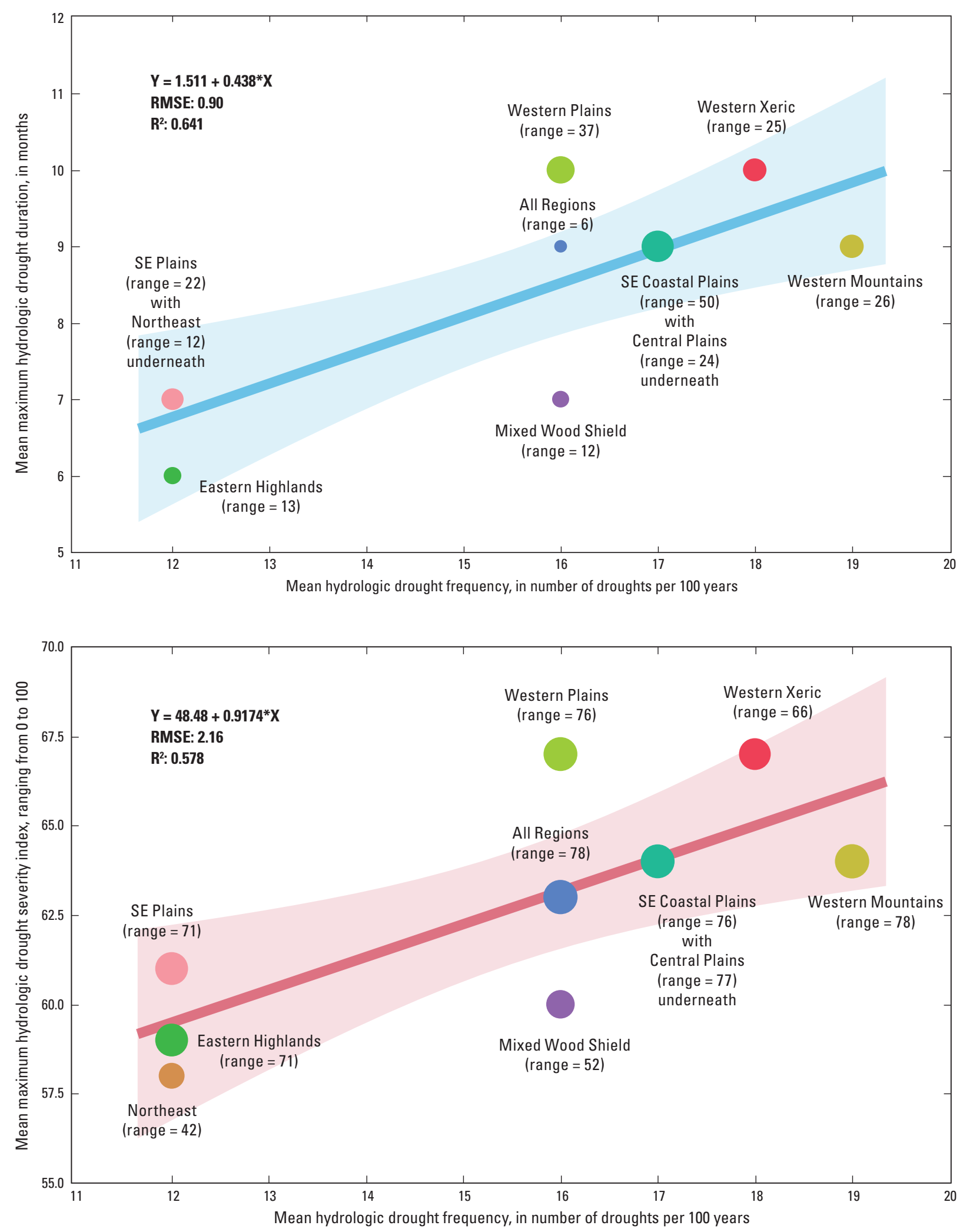

Figure 4. Relation of mean maximum hydrological drought duration and severity to mean hydrological drought frequency in the conterminous United States, 1951-2014. Lines show changes in mean maximum hydrological drought duration and severity as functions of mean hydrological drought frequency. Shading identified the 95-percent confidence interval of each relation. Circle size indicates the relative range of values in each ecoregion and all ecoregions (blue circle). (RMSE, root mean square error; $R^{2}$, $R$-squared coefficient of determination; SE, Southeast) 


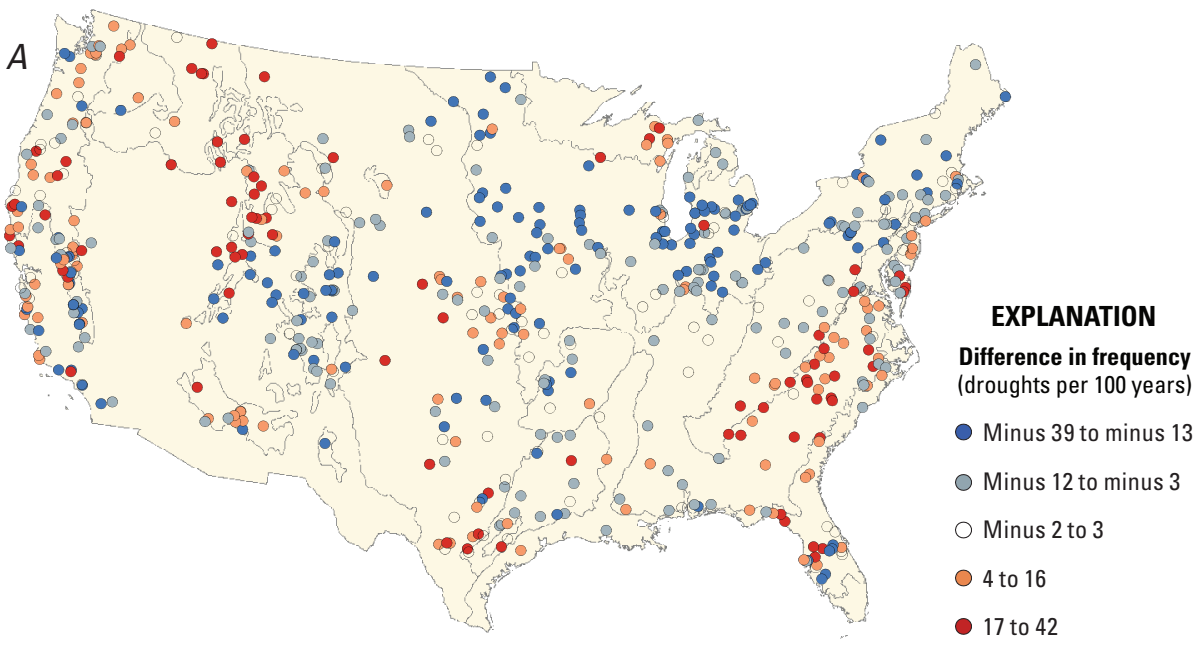

\section{Ecoregions with statistically significant drought frequency differences}

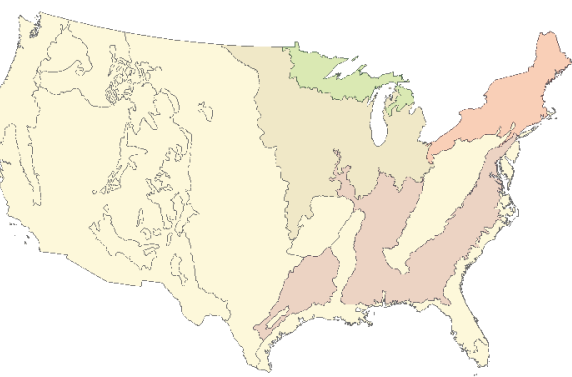

EXPLANATION

Central Plains

Mixed Wood Shield

Northeast

SE Plains

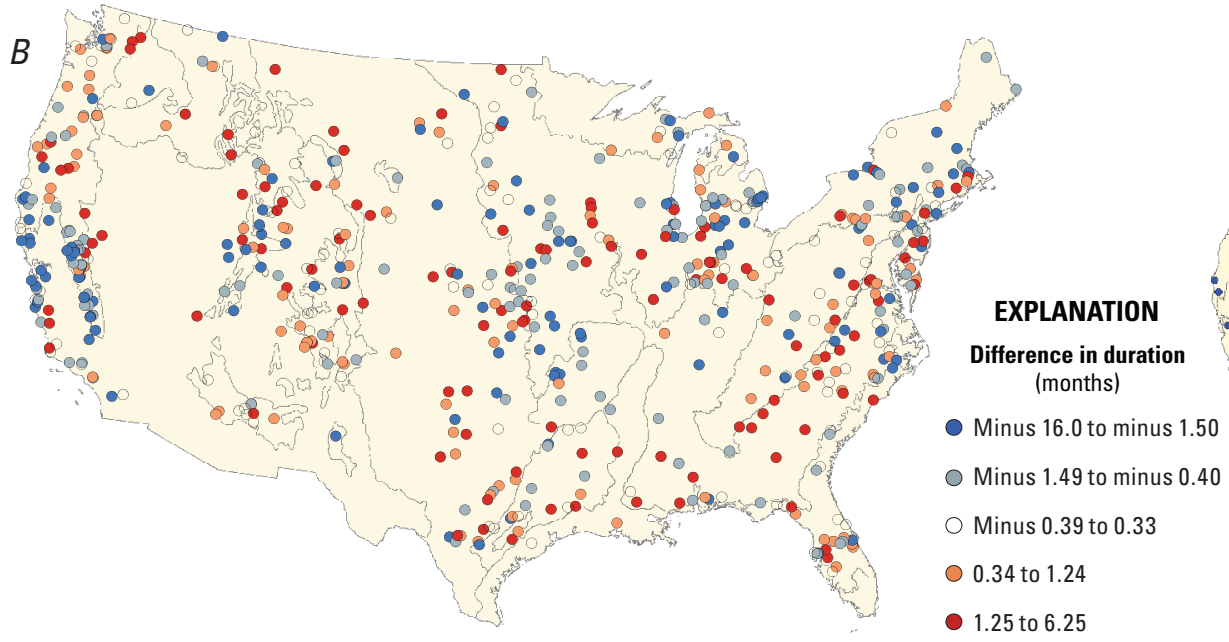

Sites with statistically significant drought duration differences

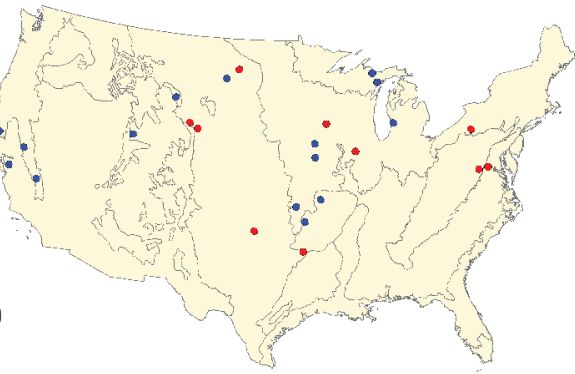

EXPLANATION

- Decrease

- Increase

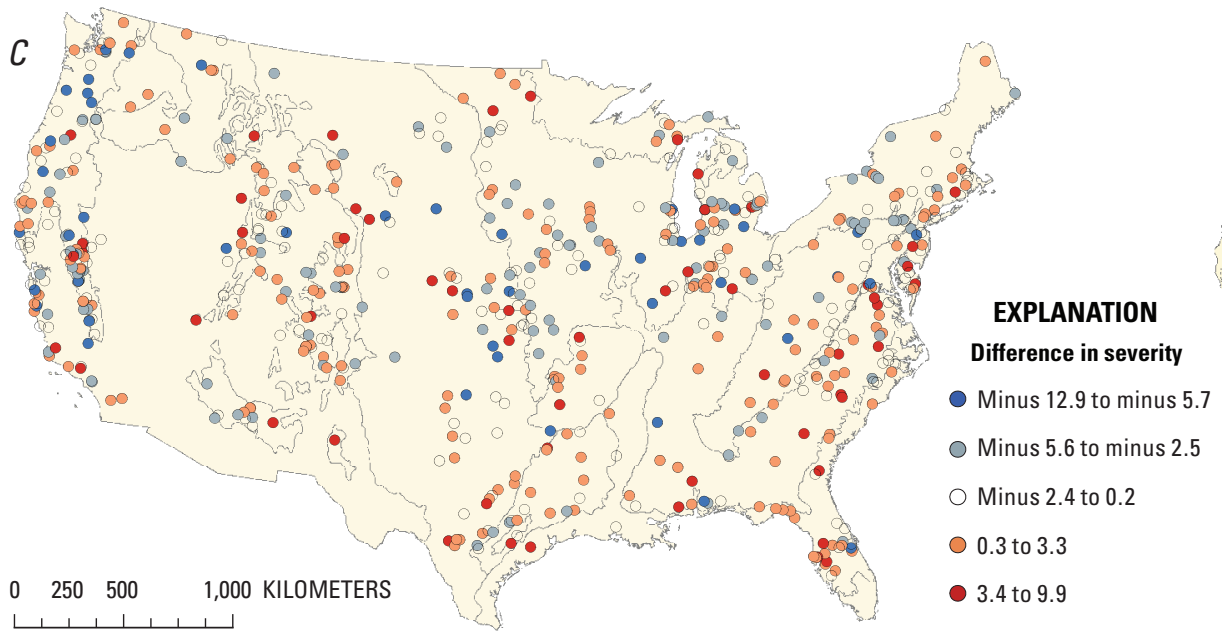

Sites with statistically significant drought severity differences

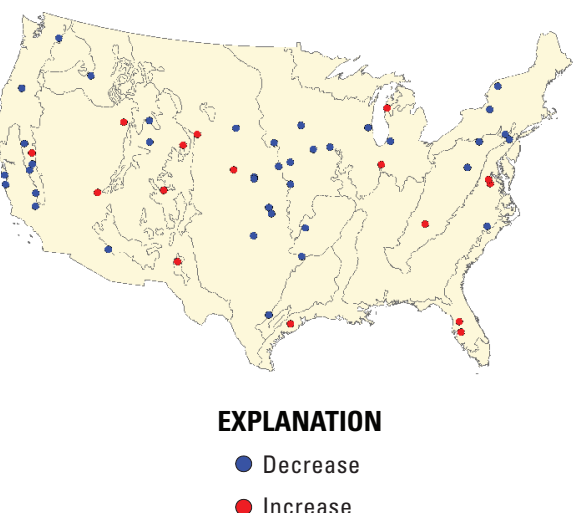

Figure 5. Differences in mean $A$, frequency, $B$, duration, and $C$, severity of droughts in the conterminous United States, 1983-2014 compared to 1951-82. Frequency insert shows ecoregions with statistically significant differences in drought frequency. Points on duration and severity insets show sites with statistically significant differences in drought duration and severity at the 95-percent confidence level $(p<0.05)$. Dot colors indicate direction or magnitude of difference. (SE, Southeast) 
Table 2. Changes in hydrological drought frequency, duration, and severity in the conterminous United States for a recent period (1983-2014) compared to an older period (1951-82), by ecoregion, 609 sites experienced drought in both time periods.

$[\%$, percent; SE, Southeast; $<$, less than $]$

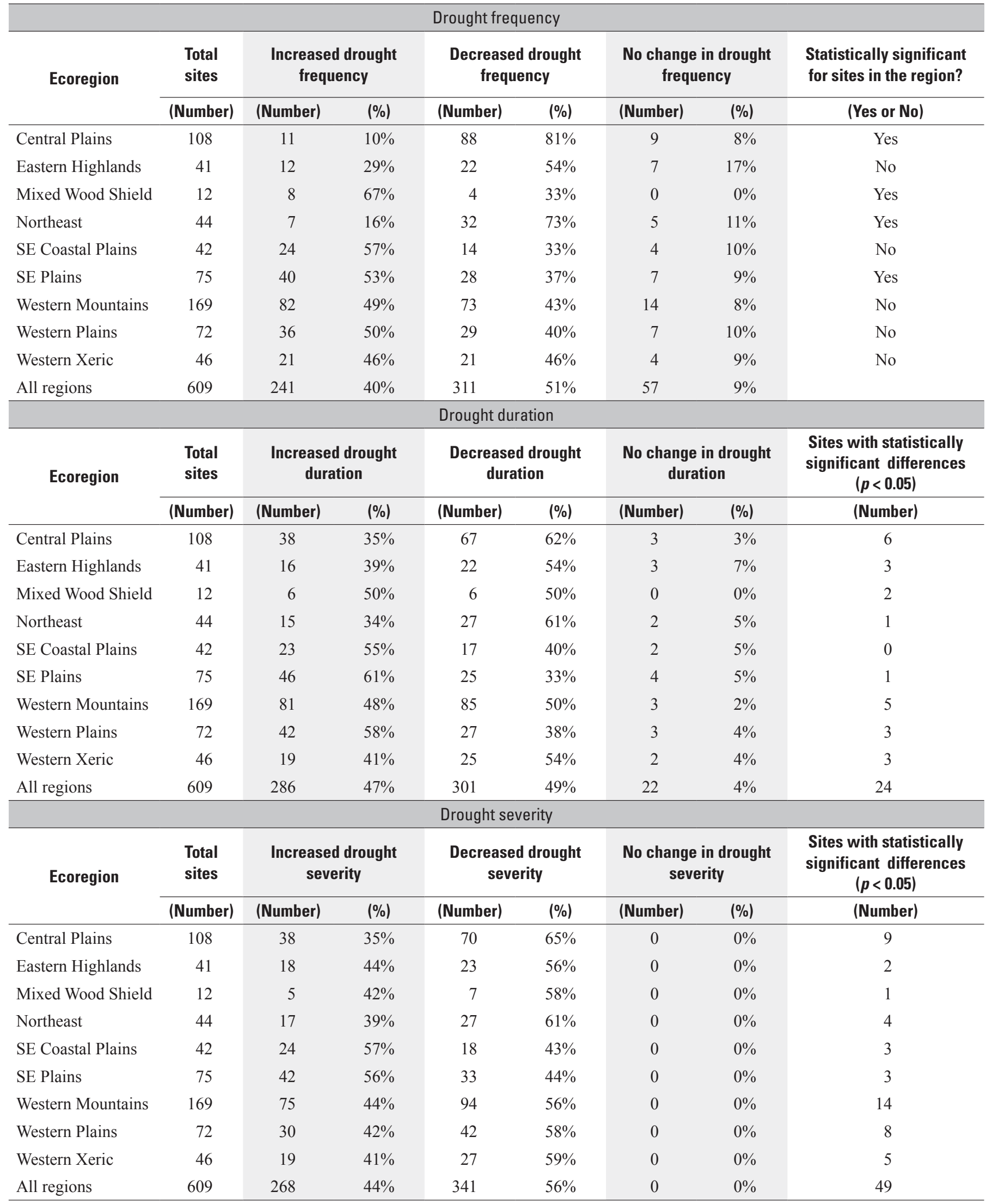


Plains, 42 of 72 sites have increased drought duration (58\%), and 30 of 72 sites have increased drought severity (42\%). In the Southeast Coastal Plains, 23 of 42 sites have increased drought duration (55\%) and 24 of 42 sites have increased drought severity (57\%). Some aggregated ecoregions exhibit decreased drought duration and severity. In the Central Plains, 67 of 108 sites (62\%) experienced decreased drought duration, and 70 of 108 sites experienced decreased drought severity $(65 \%)$. In the Northeast, 27 of 44 sites (61\%) show decreased drought duration and decreased drought severity. In the Western Xeric, 25 of 46 sites (54\%) experienced decreased drought duration, and 27 of 46 sites experienced decreased drought severity (59\%). In the Eastern Highlands, 22 of 41 sites (54\%) experienced decreased drought duration, and 23 of 41 sites (56\%) experienced decreased drought severity. The Mixed Wood Shield experienced no net change in drought duration; 6 of 12 sites $(50 \%)$ show increases, and 6 of 12 sites $(50 \%)$ show decreases. The Mixed Wood Shield experienced a small decrease in drought severity with 5 of 12 sites (42\%) showing an increase and 7 of 12 sites (58\%) showing a decrease (table 2).

\section{Comparison of Findings from This Study with Findings from Previous Investigations}

The Southeast Coastal Plains aggregated ecoregion has a high percentage of sites exhibiting increased drought frequency (57\%), a mean drought duration of (5 months), the longest single hydrological drought event (53 months), and a high maximum drought severity of (95\%) (tables 1 and 2). These results are consistent with other studies, such as Patterson and others (2013), in which a significant increase was identified for the joint probability of nearby basins simultaneously experiencing drought conditions from 1970 to 2010, and a late 20th century increase was identified for the conditional probability of these basins simultaneously being in drought. Patterson and others (2013) suggest that combined changes in climate, streamflow, and water demand affect southeastern droughts and assert that decreasing average streamflow during non-drought periods coupled with increasing water demand since the 1970s led to pressure on limited water supplies in the southeastern United States. These conclusions are reinforced by Andreadis and others (2005), who note an increase in global aridity since the 1970s and project increased aridity in the 21st century over most of the Americas, and Rind and others (1990), who identify an increasing number of droughts in the United States using the Goddard Institute for Space Studies general circulation model (GISS GCM) and note that drought effects became apparent beginning in the 1990s.

In this study the potential for persistent drought in the western United States is indicated by high frequencies of hydrological drought in the Western Mountains (19 droughts on average per 100 years), Western Xeric (18 droughts per 100 years), and Central Plains (17 droughts per 100 years) combined with relatively long mean drought durations (5 months) and high maximum drought severity percentages ( $95 \%, 95 \%$, and $94 \%$, respectively). This is reinforced by Andreadis and others (2005) who determined that droughts in the western United States in the early 2000s were among the most severe for the period of record in their analysis of 20th century droughts in the CONUS. Furthermore, Andreadis and others (2005) determined that the most severe agricultural droughts were among the most severe droughts of any kind for the period of record, and in the West most droughts were hydrological droughts. Seager and others (2007) identify a broad consensus among the results from climate models that the southwestern CONUS will dry significantly in the 21 st century and that a transition to a more arid climate is already underway. This observation is reinforced by systematic analysis of climate model simulations by Hoerling and Eischeid (2007) to determine whether an ongoing drought in the southwestern United States, within the time period of their analysis, is an early sign of departures from the historical norm. Hoerling and Eischeid (2007) conclude that the southwestern United States appears to be entering a new drought era, with conditions in this region shifting from droughts that were principally precipitation driven events enhanced by temperature to a near perpetual state of drought in the coming decades as a consequence of steadily increasing temperature.

Groisman and others (2004) found century-long increases in temperature and precipitation in the CONUS with the bulk of these increases occurring during the past three decades (1980-2010). Groisman and others (2004), for example, found that increases in precipitation and streamflow are associated with the eastern CONUS, whereas increased dryness is associated with the southwestern CONUS. These results correspond to some of the changes in regional hydrological drought identified in this study. For example, most sites in the Northeast aggregated ecoregion (73\%) have exhibited decreasing drought frequencies, and 50 percent of sites in the Western Plains aggregated ecoregion have exhibited increasing drought frequencies (table 2).

Sheffield and others (2004) show that previously reported increases in global drought are overestimated because the PDSI used to make the predictions contains a simplified model of potential evaporation that responds only to changes in temperature and thus responds incorrectly to the global warming that has occurred over recent decades (1980-2010). Using high-resolution land-surface hydrological simulations to produce a drought-forecasting index, Sheffield and others (2004) suggest that more realistic calculations, based on underlying physical principles that take into account changes in available energy, humidity, and wind speed, show little change in global drought over the past 60 years (1956-2015). Their results coincide with general observations from this study for the entire CONUS. This study shows that, on the basis of a comparison of an older period (1951-82) with a recent period (1983-2014), for the CONUS little change in 


\section{Variability of Hydrological Droughts in the Conterminous United States, 1951 through 2014}

hydrological drought frequency, duration, or severity has occurred. Variable changes in hydrological drought frequency were identified across the CONUS with 51 percent of sites experiencing decreases, 40 percent experiencing increases, and 9 percent experiencing no change (table 2). Changes in hydrological drought duration and severity across the CONUS are also variable. Overall 49 percent of sites experienced a decrease in drought duration, 47 percent experienced an increase in drought duration, and 4 percent experienced no change in drought duration. However, 56 percent of sites experienced a decrease in drought severity, 44 percent experienced an increase in drought severity, and 0 percent experienced no change in drought severity. We find that most differences in drought duration and severity are not statistically significant $(p<0.05)$ (figs. 5B inset, $5 C$ inset, table 2).

\section{Limitations}

Instances of serial dependence, when the value of a datum is affected by one or more previous data values, are a potential cause of change in measured flow patterns possibly resulting from a long-term trend, seasonal variations, dependence on some other serially correlated variable, or some combination of these (Helsel and Hirsch, 2002). This study found that any limitations associated with serial dependence of streamflows appear to be negligible. Precipitation is a primary climate driver of drought. Mapped changes in precipitation that correspond with our analysis of differences in hydrological drought illustrate the affect of precipitation as a driver of drought. Plotted differences in precipitation values (Daly and others, 2008) for the recent period (1983 through 2014) minus values for the older period (1951 through 1982) show temporal changes in precipitation consistent with our reported temporal changes in hydrological drought frequency (figs. $5 A$ and 6). These similarities in hydrological drought and precipitation changes signal a foundational relation between streamflow and precipitation over several time intervals in which any small-scale correlations associated with serial dependence of values, localized changes in flow patterns, or combinations of these influences are negligible.

Sheffield and others (2012) describe other potential physical interactions of temperature and precipitation during droughts in which evaporation may decrease because of less precipitation, resulting in higher temperatures caused by less evaporative cooling and a larger heat flux warming the air. Droughts have also been shown to co-vary with Pacific Ocean and Atlantic Ocean surface temperatures, and some assessments of drought made using indices such as the PDSI show expected increases in drought frequency and severity resulting from climate change (McCabe and others, 2004; Seager and others 2007; Sheffield and others 2009; Dai, 2013). Although combined interactions among precipitation, evaporation, transpiration, and temperature can affect hydrological drought variability in certain areas of the CONUS, in this study, we found that changes in precipitation, as a primary driver, correspond with overall changes in frequency of hydrological droughts. 


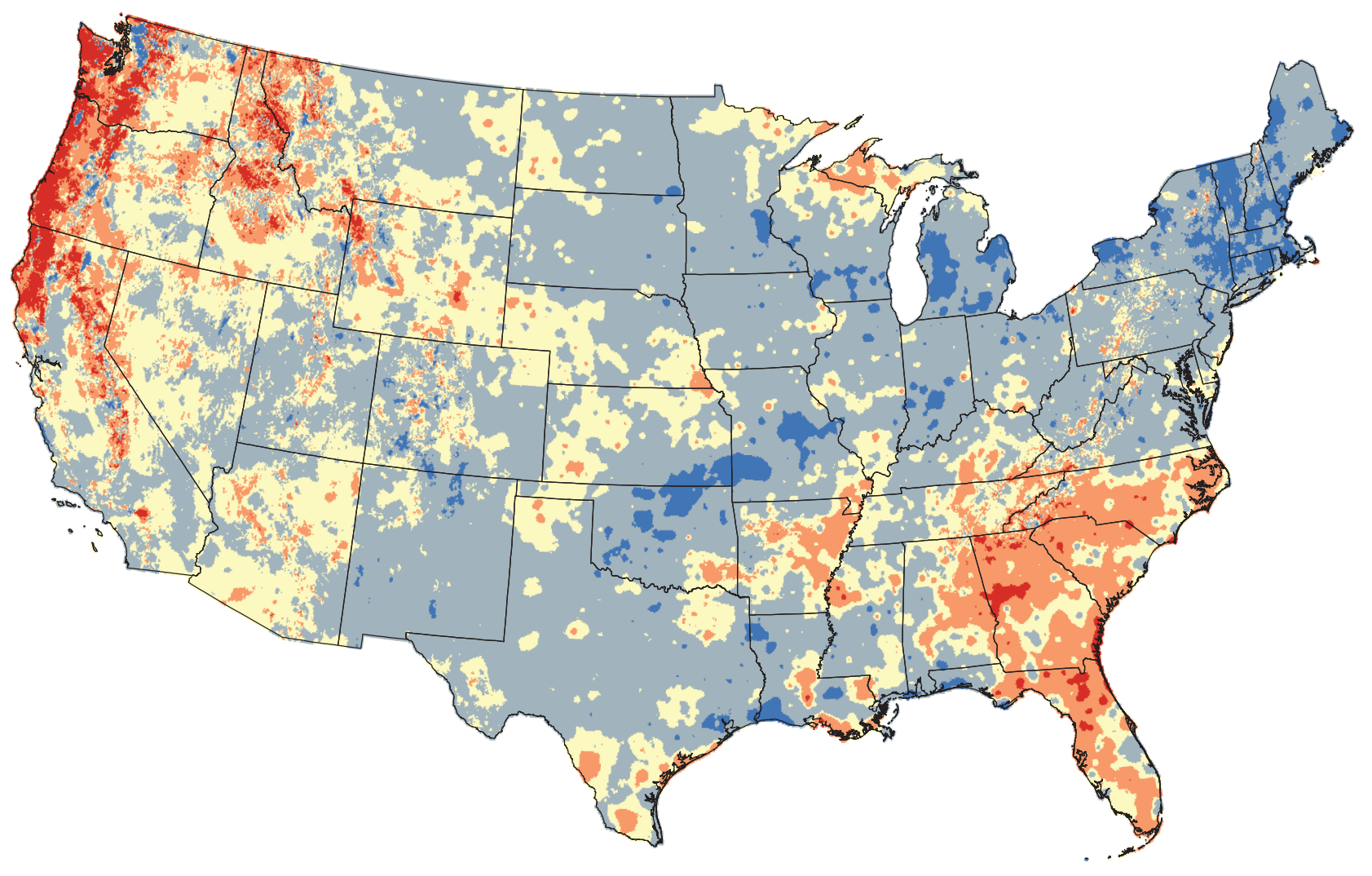

EXPLANATION

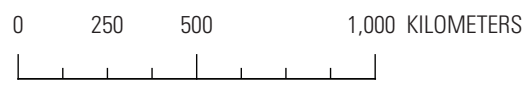

Base from U.S. Geological Survey, 1994, The National Map:

State Boundaries of the Conterminous United States, 1:2,000,000
Precipitation difference, in millimeters

(recent minus older period)

Minus 1,885 to minus 100

Minus 99 to minus 20

Minus 19 to 20

21 to 100

101 to 1,197

Figure 6. Change in precipitation in the conterminous United States between a recent period (1983 through 2014) and an older period (1951 through 1982). Precipitation differences correspond to hydrological drought differences from Falcone and others (2010). Changes in precipitation are consistent with the temporal changes in drought frequency shown in figure 5. 


\section{Summary and Conclusions}

As global climate continues to warm, concern continues to increase that climate change will have substantial effects on the occurrence and severity of hydrological droughts. When comparing an older period (1951-82) with a recent period (1983-2014), we found few sites with statistically significant changes in drought frequency, drought duration, or drought severity at a 95-percent confidence level. Some aggregated ecoregions (the Mixed Wood Shield and the Southeast Plains) and subsets of aggregated ecoregions (parts of the southeastern United States, parts of Texas and California) have experienced increases in drought frequency. Other aggregated ecoregions (the Central Plains and the Northeast) have experienced overall decreases in drought frequency. Four of 9 aggregated ecoregions have statistically significant differences in drought frequency. Changes in hydrological drought duration and severity during the specified periods were variable throughout the conterminous United States (CONUS). Parts of northern California, southern Oregon, and the area from Texas to Virginia experienced increases in drought duration. Parts of the Southeast, Western Plains, and Western Mountains aggregated ecoregions experienced increases in drought severity. At most sites, however, the observed differences in drought duration and drought severity were not statistically significant at $p<0.05$.

Relatively long mean drought durations, high mean maximum drought severity percentages, and high frequencies of hydrological drought are evident in certain parts of the CONUS, such as the Western Plains, Western Mountains, Western Xeric, Central Plains, and Southeast Coastal Plains aggregated ecoregions. When evaluated within the context of other studies these results indicate a continued potential for hydrological droughts in these parts of the CONUS.

\section{Acknowledgments}

The authors thank Pixie Hamilton, Eric Evenson, and Michael Norris of the U.S. Geological Survey for proposing and supporting this project. George E. Harlow, Jr., and Stacey Archfield of the U.S. Geological Survey are thanked for helpful advice and suggestions.

\section{References Cited}

Andreadis, K.M., Clark, E.A., Wood, A.W., Hamlet, A.F., and Lettenmaier, D.P., 2005, Twentieth-century drought in the conterminous United States: Journal of Hydrometeorology, v. 6 , p. $985-1001$.
Austin, S.H., Wolock, D.M., and Nelms, D.L., 2018, Monthly streamflows, drought indices, and supporting statistics for USGS gage stations used to identify variability of hydrological droughts in the conterminous United States, 1951 through 2014: U.S. Geological Survey, data release, https:// doi.org/10.5066/F70C4T19.

Cayan, D.R., Das, T., Pierce, D.W., Barnett, T.P., Tyree, M., and Gershunov, A., 2010, Future dryness in the southwest US and the hydrology of the early 21 st century drought: Proceedings of the National Academy of Sciences, v. 107, no. 50, p. 21271-21276.

Chung, C.H., and Salas, J.D., 2000, Return period and risk of droughts for dependent hydrologic processes: Journal of Hydrologic Engineering, v. 5, no. 3, p. 259-268.

Dai, A., 2011a, Drought under global warming: a review: WIREs Climatic Change, v. 2, p. 45-65.

Dai, A., 2011b, Characteristics and trends in various forms of the Palmer Drought Severity Index (PDSI) during 19002008: Journal of Geophysical Research, no.116, p. D12115.

Dai, A., 2013, Increasing drought under global warming in observations and models: Nature Climate Change, no. 3, p. 52-58.

Daly, C., Halbleib, M., Smith, J.I., Gibson, W.P., Doggett, M.K., Taylor, G.H., Curtis, J., and Pasteris, P.P., 2008, Physiographically sensitive mapping of climatological temperature and precipitation across the conterminous United States: International Journal of Climatology, v. 28, no. 15, p. 2031.

Downer, R., Siddiqui, M., and Yevjevich, V., 1967, Application of runs to hydrologic droughts: Colorado State University, Fort Collins, Colo., Proceedings, International Hydrology Symposium, Paper 63, v. 1, p. 496-505.

Dracup, J.A., Lee, K.S., and Paulson, E.G., 1980a, On the statistical characteristics of drought events: Water Resources Research, v. 16, no. 2, p. 289-296.

Dracup, J.A., Lee, K.S., and Paulson, E.G., 1980b, On the definition of droughts: Water Resources Research, v. 16, no. 2, p. 297-302.

Falcone, J.A., 2011, GAGES-II: geospatial attributes of gages for evaluating streamflow: U.S. Geological Survey digital spatial dataset, accessed December 25, 2013, at http://water. usgs.gov/lookup/getspatial?gagesII_Sept2011.

Falcone, J.A., Carlisle, D.M., Wolock, D.M., and Meador, M.R., 2010, GAGES: A stream gage database for evaluating natural and altered flow conditions in the conterminous United States: Ecology, v. 91, p. 621. 
Fernańdez, B., and Salas, J.D., 1999a, Return period and risk of hydrologic events. I: mathematical formulation: Journal of Hydrologic Engineering, v. 4, no. 4, p. 297-307.

Fernańdez, B., and Salas, J.D., 1999b, Return period and risk of hydrologic events. II: applications: Journal of Hydrologic Engineering, v. 4, no. 4, p. 308-316.

Frick, D.M., Bode, D., and Salas, J.D., 1990, Effect of drought on urban water supplies. I: drought analysis: Journal of Hydrologic Engineering, no. 116, p. 733-753.

Groisman, P.Y., Knight, R.W., Karl, T.R., Easterling, D.R., Sun, B., and Lawrimore, J.H., 2004, Contemporary changes of the hydrological cycle over the contiguous United States: Trends derived from in situ observations: Journal of Hydrometeorology, v. 5, no. 1, p. 64-85.

Helsel, D.R., and Hirsch, R.M., 2002, Statistical methods in water resources: U.S. Geological Survey Techniques of Water Resources Investigations Report, book 4, chap. A3, $522 \mathrm{p}$.

Hoerling, M., and Eischeid, J., 2007, Past peak water in the southwest: Southwest Hydrology, January/February, no. 18-19, 35 p.

Karl, T., Quinlan, F., and Ezell, D.S., 1987, Drought termination and amelioration: its climatological probability: Journal of Climate and Applied Meteorology, v. 26, no. 9, p. 1198-1209.

Llamas, J., and Siddiqui, M., 1969, Runs of precipitation series: Fort Collins, Colo., Colorado State University, Hydrology Paper, no. 33, 26 p.

Loaiciga, H.A., and Leipnik, R.B., 1996, Stochastic renewal model of low-flow streamflow sequences: Stochastic Hydrology and Hydraulics, v. 10, no. 1, p. 65-85.

Maidment, D.R., 1992, Handbook of hydrology: New York, McGraw-Hill, Inc., ISBN: 0-07-039732-5, 1424 p.

McCabe, G.J., Palecki, M.A., and Betancourt, J.L., 2004, Pacific and Atlantic ocean influences on multi-decadal drought frequency in the conterminous United States: Proceedings of the National Academy of Sciences, v. 101, p. 4136-4141.

McCabe, G.J., and Wolock, D.M., 2014, Spatial and temporal patterns in conterminous United States streamflow characteristics: Geophysical Research Letters, v. 41, iss. 19, p. 6889-6897, doi:10.1002/2014GL061980.

Mishra, A.K., and Singh, V.P., 2011, Drought modeling-a review: Journal of Hydrology, v. 403, p. 157-175.
Mishra, A.K., Singh, V.P., and Desai, V.R., 2009, Drought characterization: a probabilistic approach: Stochastic Environmental Research and Risk Assessment, v. 23, no. 1, p. $41-55$.

Nalbantis, I., and Tsakiris, G., 2009, Assessment of hydrological drought revisited: Water Resources Management, v. 23, no. 5, p. 881-897.

Patterson, L.A., Lutz, B.D., and Doyle, M.W., 2013, Characterization of drought in the South Atlantic, United States: Journal of the American Water Resources Association, v. 49, iss. 6, p. 1385-1397, doi:10.1111/jawr.12090.

Rind, D., Goldberg, R., Hansen, J., Rosenzweig, C., and Ruedy, P., 1990, Potential evapotranspiration and the likelihood of future drought: Journal of Geophysical Research, v. 95, p. 9983-10004.

Seager, R., Ting, M., Held, I., Kushnir, I.Y., Lu, J., Vecchi, G., Huang, P.H., Harnik, N., Leetma, A., Lau, N.C., Li, C., Velez, J., and Naik, N., 2007, Model projections of an imminent transition to a more arid climate in southwestern North America: Science, v. 316, p. 1181-1184.

Sen, Z., 1976, Wet and dry periods for annual flow series: Journal of the Hydraulic Engineering Division, v. 102, p. 1503-1514.

Sen, Z., 1980a, Regional drought and flood frequency analysis, theoretical consideration: Journal of Hydrology, ASCE, v. 46, p. 265-279.

Sen, Z., 1980b, Statistical analysis of hydrologic critical droughts: Journal of the Hydraulic Division, ASCE, v. 106, no. 1, p. 99-115.

Sheffield, J., Andreadis, K.M., Wood, E.F., and Lettenmaier, D.P., 2009, Global and continental drought in the second half of the twentieth century: Severity-area-duration analysis and temporal variability of large-scale events: Journal of Climate, v. 22, p. 1962-1981, doi:10.1175/2008JCLI2722.1.

Sheffield, J., Goteti, G., Wen, F., and Wood, E.F., 2004, A simulated soil moisture based drought analysis for the United States: Journal of Geophysical Research, v. 109, iss. D24, p. 108, doi:10.1029/2004JD005182.

Sheffield, J., and Wood, E., 2008, Projected changes in drought occurrence under future global warming from multi-model, multi-scenario, IPCC AR4 simulations: Climate Dynamics, v. 31, p. 79-105.

Sheffield, J., Wood, E.F., and Roderick, M.L., 2012, Little change in global drought over the past 60 years: Nature, v. 491, p. 435-440, doi:10.1038/nature11575. 
16 Variability of Hydrological Droughts in the Conterminous United States, 1951 through 2014

Strzepek, K., Yohe, G., Neumann, J., and Boehlert, B., 2010, Characterizing changes in drought risk for the United States from climate change: Environmental Research Letters, v. 5, no. 4,9 p.

Yevjevich, V., 1967, An objective approach to definitions and investigations of continental hydrologic droughts: Fort Collins, Colo., Colorado State University, Hydrology Paper 23, https://dspace.library.colostate.edu/

bitstream/handle/10217/61303/HydrologyPapers_n23. pdf $\% 3$ Bsequence $\% 3 \mathrm{D} 1$. 
For additional information, contact:

Director, Virgina Water Science Center U.S. Geological Survey

1730 East Parham Road,

Richmond, VA 23228

or visit our website at: http://va.water.usgs.gov/

Publishing support provided by West Trenton Publishing Service Center 
